\title{
Preliminary Identification of Urban Park Infrastructure Resilience in Semarang Central Java
}

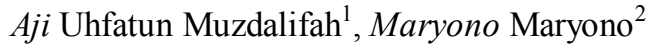 \\ ${ }^{1}$ Master Program of Environmental Science, School of Postgraduate Studies, Diponegoro University, Semarang - Indonesia \\ ${ }^{2}$ Department of urban and Regional P lanning, Faculty Engineering, Diponegoro University, Semarang-Indonesia
}

\begin{abstract}
Park is one of the spot green infrastructure. There are two major characteristic of park, first Active parks and second passive park. Those of two open spaces have been significant on the fulfillment of urban environment. To maintenance the urban park, it is very importance to identify the characteristic of active and passive park. The identification also needs to fostering stakeholder effort to increase quality of urban park infrastructure. This study aims to explore and assess the characteristic of urban park infrastructure in Semarang City, Central Java. Data collection methods conduct by review formal document, field observation and interview with key government officer. The study founded that urban active parks infrastructure resilience could be defined by; Park Location, Garden Shape, Vegetation, Support Element, Park Function, and Expected Benefit from Park Existence. Moreover, the vegetation aspect and the supporting elements are the most importance urban park infrastructure in Semarang.
\end{abstract}

\section{Introduction}

Currently, environmentally sound in urban planning the facing urban climate hazard which its impact such as urban infrastructure resilience. Fostering the urban infrastructure resilience for sustainable cities life becoming major requirement. One of the main issues in urban spatial planning to provide comfort, beauty and health city is the resilience of urban green open space. Increasing empirical evidence of climate hazard, such as flood, windstorm, drought, indicates that the presence of natural disturbance should be manage properly [1].

For the institutional resilience perspective, Indonesia government has issued guidelines concerning to the provision and utilization of green open space trough the Regulation of the Minister of Public Works No. 05 / PRT / M / 2008 [2]. Refers to the guidelines provision and utilization of green open space in urban area, some parameter should be indentify such as open land which belongs to a unity of non-natural green open space, social aspect in green open space, aesthetic functions. recreative, educational or other activities that may use the green open space. The urban green open space resilience consist of socio-economy and engineering resilience [3]. Moreover, in the perspective of institution resilience, urban park infrastructure resilience in developing cities also facing issues associated to the flood hazard and disaster waste, for example handling urban green waste in disaster event [4]

Resilience of parks, open space and other forms of green space also provide essential services that are critical to both urban ecological functioning and integrity
[5]. The resilience of green open space such as park have a positive correlation with the ecological impact on the city environment, for example, contribute to the balance of physical urban development and human development in the context of city amenity, comfort and convenience $[5,6]$. However, characteristic of physical urban open space and green urban open space mostly tend to more influence for the degree of resilience [6]

\section{Literature review}

\subsection{Green Infrastructure}

Regional and Urban Development need green infrastructure for ecological balancing. Sufficient Green infrastructure will perform human life by saving water, air from any pollution and disturbance. Therefore green infrastructure resilience is significant during rapid development, irregular and dangerous environment hazard. Green infrastructure consist of two major part, the first one is space and vegetation and the second is physical form of space at which could be define as natural and man made material [6,7].

Green infrastructure consists of space, vegetation and its element. Green infrastructure could be defned as open spaces, natural areas, urban woodland and parks; green streets, squares and public realm; sustainable drainage systems and healthy waterways, cycleways and pedestrian routes within our city environments; and smaller scale green roofs, walls and facades [8]. Green Infrastructure is the network of green places and

Corresponding author: maryono@pwk.undip.com 
water systems that delivers multiple environmental, social and economic values and services to urban communities[9].

\subsection{Urban park infrastructure resilience}

Urban parks are defined as delineated open space areas, mostly dominated by vegetation and water, and generally reserved for public use[10]. The scope and speed of current changes demands that urbanists define compelling visions and integrated design measures for shaping resilient cities [11]. While Urban resilience could be define as the ability of urban asset, location and/ or system to provide predictable performance - benefits and utility and associated rents and other cash flows - under a wide range of circumstances $[12,13]$. According to the definition urban park infrastructure resilience could be defined as ability of an urban park infrastructure system and all its consitutent socio-ecological and socio-technical networks across temporal and spatial scales-to mantain or rapidly return to desire functions in theface of disturbance, to adapt to change, and to quickly transform systems that limir currentor future adaptive capacity $[12,13,14]$

Assessing the urban park resilience should be viewed as an important part of urban and community development rather than just as settings for recreation and leisure. Urban infrastructure and form encompass the built environment such as buildings, transportation networks, energy, and water grids (utilities), along with urban green space and parks [12,13]. Moreover, assessment of urban park resilience include should assess the domestic gardens which it is important component in many people's lives. However stakeholder intention and attitudes towards this resilience issues is very poor. They not yet understand that the importance function of domestic gardens such as maintenance the of the thermal comfort in their residents, reduce domestic energy consumption and minimize storm run-off. Moreover, stakeholder not yet realized that domestic garden provide environment from greenhouse gas emissions rather than off setting them.

Resilience of urban park infrastructure is need to against climate change impact. From the perspective of infrastructure system, resilience of urban park will importance for ecological aspect such as providing enough water in long term impact[15]. Moreover, garden cities have been use as one of the principal theme in cities development[16]. maintenance urban park resilience will be arise other social benefit such as economics perspective and ecosystem benefit such as biodiversity, moreover, degree urban environment also will be be increase within the availability of parks and other open spaces. There are three major component of urban park resilience; (1) urban parks in economic development strategies; (2) parks asrecreaton spaces to improve citzens health outcomes; and (3) function of green infrastructure parks associated with the improvement stormwater [17]. Other attributes associated with urban park resilience are; the utility of park, physical activity that usually occur in park, its features, conditions, aethetics, safety and social environments [3].

\section{Methodlogy}

\subsection{Study area and issues}

As shown in figure 1, Semarang is one of

the Unique Cities not only for his citizen, but also for Central Java Province and Indonesia. This city is one of 100 Resilience Cities network at which getting more intention in climate change adaptation [18,19,].

In recent development, Semarang faces various complex environmental problems, such as flood and inundated area $[20,21]$. The inundated area, climate hazard and other environmental issues in Semarang is tend to increase have an impact on the deterioration of the quality of the environment. This study aimed to addressed effort especially for fostering in urban park resilience.

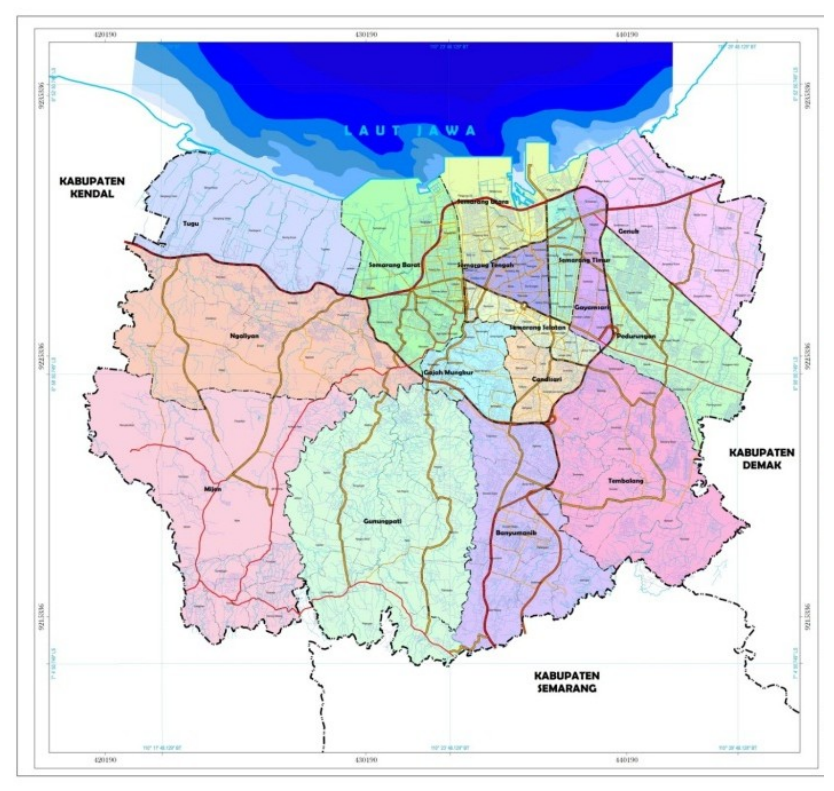

Fig. 1. Administrations Map of Semarang

The government of Semarang City have been realize concerning to their environmental issues. They state formally in the local regulation No. 6 of 2010 concerning to Long Term Development Plan Area (RPJPD) Semarang City periode 2005-2025 [22]. Refers to the document, the main environmental issue in Semarang are the degradation of environmental quality and global warming. Moreover, in their Regional Spatial Plan of Semarang City Year 2010-2030, explained that green open space is less then $20 \%$, so they must increase the number of their urban green open space. one of the importance component is city park [23]. A city park is a park intended to serve residents of one city or part of the city. The park serves a minimum of 480,000 residents with a minimum standard of $0.3 \mathrm{~m} 2$ per city dweller, with a minimum park area of $144,000 \mathrm{~m} 2$ [2]. The park 
can be shaped as green open space (green field), equipped with recreational facilities and sports, and sports complex with a minimum of $80 \%-90 \%$ green open space. All these facilities are open to the public. The vegetation species selected in the form of annual trees, and shrubs are planted in clusters or spread as microclimate creatures or as a barrier between activities.

Urban parks and green open space besides serve as a function of beauty, also serves as a space of community interaction, sports facilities, and the lungs of the city. Awareness of Semarang City Government in the procurement and management of green open space is indicated by the allocation of land of green space utilization in regulation (Spatial Plan of Area) which is quite dominant. In Semarang City Center, the presence of green open space is in: private gardens, 90 units parks currently managed by the Housing and Settlement Service and from the greening / tree by the roadside.

\subsection{Data collection and analysis}

The focus of this study is to identify the infrastructure component of urban park that influence the degree of it resilience. The study will classify the urban park infrastructure base on two major characteristic of urban park namely active park and passive park. Moreover this study will explore the condition, status of utilization in active and passive park.

This research is a qualitative and quantitative approach. Primary data conducted by field observation, and interview with key stakeholder, while Secondary data in this study were obtained from literature and related institutions. Primary data getting fromsurvey and interview result. Moreover, data collection is also conducted by examining the various documents related to the recent study of urban parks, stakeholder and government.

The statistics descriptive used to analyze and utilize the data that has been collected. Moreover, the description content of factors urban park resilience such as features, conditions, aethetics, safety and social environments.

\section{Result and discussion}

Base on the field survey, this study have classify the characteristic of urban park in Semarang as urban active park and urban passive park [24]. The urban active park is that the characteristic of park which community use urban infrastructure for refreshing, play or use for physical exercise and sport. While the passive urban park is the there is no urban park infrastructure for refreshing, play or use for physical exercise and sport $[24,25]$. In passive urban park, the urban park infrastructure is design only for aesthetics, security and safety, and amenities. Urban active park in semarang mostly use for jogging, sport and other physical exercise, playing, and several urban park there economic activities such as urban street vendors.

Table 1 shown observation result concerning to the characteristic of urban active park and urban passive park. As shown in table, there are 76 urban active park and 167 urban passive park in Semarang. In accordance Mostly urban park found in Semarang Tengah District with totally 47 urban park. While the smallest availability of urban park founded in Tembalang District.

Table 1. Amount of Urban Parks Infrastructure in Semarang

\begin{tabular}{|c|c|c|c|c|}
\hline \multirow{2}{*}{ Districts } & \multicolumn{2}{|c|}{ Type Of Park } & \multirow{2}{*}{ Amount } & \multirow{2}{*}{$\begin{array}{c}\text { Total Area } \\
\left(\mathbf{m}^{2}\right)\end{array}$} \\
\hline & Active & Passive & & \\
\hline Banyumanik & 6 & 8 & 14 & $18,595.1$ \\
\hline Candisari & 1 & 10 & 11 & $14,206.5$ \\
\hline Gajahmungkur & 3 & 15 & 18 & $24,102.5$ \\
\hline Gayamsari & 2 & 2 & 4 & $2,016.0$ \\
\hline Mijen & 2 & 1 & 3 & $36,000.0$ \\
\hline Ngaliyan & 1 & 1 & 2 & 600.0 \\
\hline Pedurungan & 30 & 5 & 35 & $68,396.0$ \\
\hline Semarang Barat & 2 & 33 & 35 & $32,865.3$ \\
\hline Semarang Selatan & 9 & 13 & 22 & $55,473.8$ \\
\hline Semarang Tengah & 1 & 46 & 47 & $30,793.6$ \\
\hline Semarang Timur & 9 & 25 & 34 & $26,383.0$ \\
\hline Semarang Utara & 9 & 6 & 15 & 7.276 .4 \\
\hline Tembalang & 0 & 1 & 1 & $2,578.0$ \\
\hline Tugu & 1 & 1 & 2 & $17,645.0$ \\
\hline Jumlah & 76 & 167 & 243 & $336,931.2$ \\
\hline
\end{tabular}

This study founded that the characteristic of urban park follow the direction of the minister of interior number 14 of 1988, that the greening density of urban parks in Semarang is between $80 \%-90 \%$ of the land area. Totally there are $336,931.2 \mathrm{~m}^{2}$. As classify in district level, Pedurungan district have totally $68,396 \mathrm{~m}^{2}$, it is the largest area comparing to the other of district. Mijen district have a smallest area of park compare to other district. The characteristics of urban park in Semarang mostly near the central of cit for passive urban park, and near the public activity such as housing and office for active urban park.

Table 2. Typology of Urban Park Infrastructure Resilience in Semarang central Java

\begin{tabular}{|c|c|}
\hline Type of Urban Park & $\begin{array}{l}\text { Typologi Urban Park Infrastructure } \\
\text { Resilience }\end{array}$ \\
\hline Active & $\begin{aligned} & \text { The probability of resilience issues } \\
& \text { (sorted from the highest disturbance) } \\
& \text { 1. } \text { Social resilience } \\
& \text { 2. } \text { Amenities resilience } \\
& \text { 3. } \text { Economic resilience } \\
& \text { 4. } \text { Spatial boundary of plan } \\
& \text { resilience } \\
& \text { 5. } \text { Education resilience } \\
& \text { 6. } \text { Ecological resilience } \\
&\end{aligned}$ \\
\hline Passive & $\begin{aligned} & \text { The probability of resilience issues } \\
& \text { (sorted from the highest disturbance) } \\
& \text { 1. } \text { Ecological resilience } \\
& \text { 2. } \text { Spatial boundary of plan } \\
& \text { resilience } \\
& \text { 3. } \text { Education resilience } \\
& \text { 4. } \text { Economic resilience } \\
& \text { 5. } \text { Social resilience } \\
& \text { 6. } \text { Amenities resilience }\end{aligned}$ \\
\hline
\end{tabular}

Many literature have been discussion related to resilience such as, ecology, engineering, psychology, complex adaptive system, economy, and social perspective $[26,27,28]$. This study identify probability of urban park infrastructure resilience refers to the characteristic, function [6], at which the resilience can be identify as shown in table 2 . This study founded the six 
resilience of urban park infrastructure in Semarang. The resilience may vary depending on the characteristic of park.

The highest disturbance from the urban park infrastructure is concerning to social resilience. While for passive urban park infrastructure the highest disturbance is related to ecological resilience. The social resilience refers to the main function of active urban park related to to human activity such as for recreation, sport activity and other physical activity. Ecological resilience refers to the main function of the passive urban park infrastructure at which dominant for ecological perspective. Both for active and passive urban park infrastructure, economic resilience may be disturb at the middle level, since for the economic perspective there is not yet found the importance of economic both in the perspective of activity in park or economic value of park.

Amenities of urban park infrastructure resilience is that associated to the physical form of urban park. For example when the disaster attack such as flood the form of urban park will destroyed and huge of green waste will be generated in urban area [3]. For the Economic resilience of urban park infrastructure, this study found that main issues of resilience mostly concerning to the basic understanding of economic value of activity in urban park or value of infrastructure of park. There is no study or formal document concerning to the economic valuation of availability park in Semarang. Educational resilience of urban park infrastructure associated to the flora and fauna that may life in urban park. urban park could be design as a place for increase biodiversity

\section{Conclusion}

Base on the field observation, interview and cross check with the secondary data, this study found characteristic of urban park infrastructure resilience as follow:

- Urban park infrastructure resilience could be defined best on the its physical condition, form and function for city life

- In Semarang estimated found 243 urban infrastructure park. Consist of 76 active urban park infrastructure and 167 passive urban park.

- The total area of urban park infrastructure are $336,931.2 \mathrm{~m}^{2}$. Refers to the number, Semarang Tengah district found the highest of urban park with 47 urban parks. Refers to the area, Pedurungan district have the largest urban park with $68,396.0 \mathrm{~m}^{2}$

- The major classification of urban park infrastructure resilience could be define as resilience of active urban park infrastructure and passive urban park infrastructure.

- In active urban park infrastructure resilience, the disturbance that may reduce are Social resilience, Amenities resilience, Economic resilience, Spatial boundary of plan resilience, Education resilience and Ecological resilience
- In passive urban park infrastructure resilience, the disturbance that may reduce are Ecological resilience, Spatial boundary of plan resilience, Education resilience, Economic resilience, Social resilience and Amenities resilience

\section{Acknowledgment}

This research is funded by the Directorate of Research and Community Services, Ministry of Research, Technology and Higher Education for year 2017 with contract number 344-42/UN7.5.1/PP/2017

\section{References}

1 A. Chiesura, Landsc. Urban Plan., vol. 68, pp. 129138, (2004).

2 Indonesia, Ministry of Public Work No. 5 Year 2008 Guidelines of Providing and Utilization of Urban Green Open Space. (2008)

3 B. Stephan, P.John, E.Henrik. Urban studies, 52.7, pp 1321-1338. (2015)

4 H. Nakayama, T. Shimaoka, K. Omine, Maryono, P. Patsaraporn, O. Siriratpiriya, (2013). Journal of Disaster Research, 8 (3), pp. 456-464, (2013)

5 J. R. Wolch, J. Byrne, and J. P. Newell, "Landsc. Urban Plan., vol. 125, pp. 234-244,(2014).

6 K.Tzoulas, K.Korpela, S.Venn, V. Yli-Pelkonen, A.Kaźmierczak, Jari Niemela, P. James, andsc. Urban Plan., vol. 81-3, pp. 167-178,(2007).

7 M.A. Benedict, E.T. McMahon, Green infrastructure: linking landscapes and communities, Monograph S Eries (2012)

8 C. Luebkeman and J. Hargrave, Arup, (2014).

9 M. Herold, J. S. Latham, a. Di Gregorio, and C. C. Schmullius, J. Land Use Sci., vol. 1, no. 2-4, pp. 157-168, Dec. (2006).

10 GR McCormack, M Rock, AM Toohey, D Hignell, Health \& place, vol. 16, pp. 712-726, (2010)

11 C. C. Konijnendijk, M. Annerstedt, a. B. Nielsen, and S. Maruthaveeran, Int. Fed. Park. Recreat. Adm., no. January, pp. 1-68, (2013).

12 S.Meerow, J.P, Newell, M. Stults, Land and urban planning, vol 147, pp. 38-49. (2016)

13 L Chelleri - Documents d'Anàlisi Geogràfica, 2012 dag.revista.uab.es

14 D. Levitz, "The Role of Parks in Shaping Successful Cities," no. May, (2014).

[15 G. R. Mc Cormack, M. Rock, A. M. Toohey, andD. Hignell, Heal. Place, vol. 16, no. 4, pp. 712-726, (2010).

16 Cameron, Ross W.F, Urban Forestery \& Urban Greening 11 (2012) 129-137. Elsevier, (2012)

17 McCormack, G. R., Rock, M., Toohey, A. M., \& Hignell, D. (2010). 16(4), 712-726. 
18 http://www.100resilientcities.org/cities/semarang/

19 D.Harwitasari, J.A Van Ast, J.flood risk management, 2011

20 I.Buchori, A.Sugiri, S.P. Hadi, American Journal of Environmental Sciences, vol 11.2, pp. 62-75. 2015)

21 P. Khadiyanta, S. Dewantari - Procedia-Social and Behavioral Sciences, (2016)

22 Semarang City Government, Long Term Planning of Semarang Development 2005-2025, bappeda.semarangkota.go.id, (2010)

23 The government of Semarang, Local State Regulation No. 14 year 2011 concerning Spatial Planning of Semarang City 2011-2031
24 K.M. Roche, J. Gittelsohn, A.F. Yan, N.M, Astone, J of Andolescent Health, Vol. 45, pp. S64-s70 (2009)

25 D.A. Cohen, T.Marsh, S. Williamson, K.P. Derose, H.Martinez, C.Setodji, T.M Mckenzie, Preventive Madicine, vol. 50, pp. S9-S12, (2010).

26 P.M-Breen, J.M. Anderies, Resilience: A literature review, Bellagio Initiative partners: Institute of Development Studies (IDS), the Resource Alliance and the Rockefeller Foundation. (2011).

27 WN Adger, Progress in human geography, vol 3, (2000)

28 C Folke - Global environmental change, vol 16, pp. 253-267. (2006) 